\title{
Exosomes: vehicles for the transfer of toxic proteins associated with neurodegenerative diseases?
}

\author{
Shayne A. Bellingham ${ }^{1,2,3}$, Belinda B. Guo ${ }^{1,2}$, Bradley M. Coleman ${ }^{1,2}$ and Andrew F. Hill ${ }^{1,2,3}$ * \\ ${ }^{1}$ Department of Biochemistry and Molecular Biology, The University of Melbourne, Melbourne, VIC 3010, Australia \\ ${ }^{2}$ Bio21 Molecular Science and Biotechnology Institute, The University of Melbourne, VIC 3010, Australia \\ ${ }^{3}$ Mental Health Research Institute, Melbourne Brain Centre, The University of Melbourne, Melbourne, VIC 3010, Australia
}

\section{Edited by:}

Claudia Verderio, CNR Institute of

Neuroscience, Italy

Reviewed by:

Claudia Verderio, CNR Institute of Neuroscience, Italy

Roberto Chiesa, Istituto di Ricerche Farmacologiche Mario Negri, Italy

*Correspondence:

Andrew F. Hill, Department of Biochemistry and Molecular Biology,

Bio21 Molecular Science and Biotechnology Institute, University of Melbourne, 30 Flemington Road, Parkville, VIC 3010, Australia. e-mail:a.hill@unimelb.edu.au
Exosomes are small membranous vesicles secreted by a number of cell types including neurons and can be isolated from conditioned cell media or bodily fluids such as urine and plasma. Exosome biogenesis involves the inward budding of endosomes to form multivesicular bodies (MVB). When fused with the plasma membrane, the MVB releases the vesicles into the extracellular environment as exosomes. Proposed functions of these vesicles include roles in cell-cell signaling, removal of unwanted proteins, and the transfer of pathogens between cells. One such pathogen which exploits this pathway is the prion, the infectious particle responsible for the transmissible neurodegenerative diseases such as Creutzfeldt-Jakob disease (CJD) of humans or bovine spongiform encephalopathy (BSE) of cattle. Similarly, exosomes are also involved in the processing of the amyloid precursor protein (APP) which is associated with Alzheimer's disease. Exosomes have been shown to contain full-length APP and several distinct proteolytically cleaved products of APP, including $A \beta$. In addition, these fragments can be modulated using inhibitors of the proteases involved in APP cleavage. These observations provide further evidence for a novel pathway in which PrP and APP fragments are released from cells. Other proteins such as superoxide dismutase I and alpha-synuclein (involved in amyotrophic lateral sclerosis and Parkinson's disease, respectively) are also found associated with exosomes. This review will focus on the role of exosomes in neurodegenerative disorders and discuss the potential of these vesicles for the spread of neurotoxicity, therapeutics, and diagnostics for these diseases.

Keywords: exosomes, prions, Alzheimer's disease, exosomal shuttle RNA, neurodegenerative diseases

\section{INTRODUCTION}

Most, if not all, types of mammalian cells release small membranous vesicles known as exosomes. In addition to their protein content these vesicles have recently been shown to contain messenger RNA (mRNA) and microRNA (miRNA) species. Roles for these vesicles include cell-cell signaling, removal of unwanted proteins, and transfer of pathogens, such as prions, between cells. Prions are the infectious particles that are responsible for transmissible neurodegenerative diseases such as Creutzfeldt-Jakob disease (CJD) of humans or bovine spongiform encephalopathy (BSE) of cattle. Proteins associated with certain neurodegenerative disorders, such as Alzheimer's and Parkinson's disease and the prion diseases CJD and BSE, can be selectively incorporated into intraluminal vesicles of MVBs and subsequently released into the extracellular environment in exosomes. As exosomes can be isolated from circulating fluids such as serum, urine, and cerebrospinal fluid (CSF), they provide a potential source of biomarkers for neurological conditions. This review will describe the roles these vesicles play in neurodegenerative disease and their potential for diagnostics through the analysis of their protein and genetic cargo.

\section{EXOSOME BIOGENESIS AND PROTEIN SORTING}

Exosome biogenesis occurs within multivesicular bodies (MVBs) in the endosomal system, which co-ordinates cargo transport between the plasma membrane, trans-Golgi network (TGN), and lysosomes. Collectively, the endosomal system consists of primary endocytic vesicles, early endosomes, and MVBs. Early endosomes are located near the cell membrane where they act as the first port of call for primary endocytosed vesicles which are either recycled to the plasma membrane or targeted to MVBs. Proteins that are sequestered to the limiting membrane of MVBs can be selectively incorporated into intraluminal vesicles (ILVs) by invagination of the MVB membrane. From here, proteins are either degraded by fusion of the MVB with the lysosomal membrane and release of the ILV's into the lysosome, or alternatively, they can be released into the extracellular environment as exosomes when MVBs fuse with the plasma membrane (Figure 1). Protein sorting and packaging into ILVs occurs in a regulated manner, involving a variety of mechanisms including mono-ubiquitination and the ESCRT (endosomal sorting complex required for transport) machinery (Hicke, 2001), association with lipid rafts (de Gassart et al., 2003), higher-ordered oligomerization (Vidal et al., 1997; Fang et al., 2007), and segregation into microdomains by ceramide (Trajkovic et al., 2008).

The existence of multiple mechanisms for protein sorting into exosomes has raised the possibility that the various pathways could generate multiple populations of MVBs, containing ILVs with potentially distinct properties and fates (van Niel et al., 2006; 


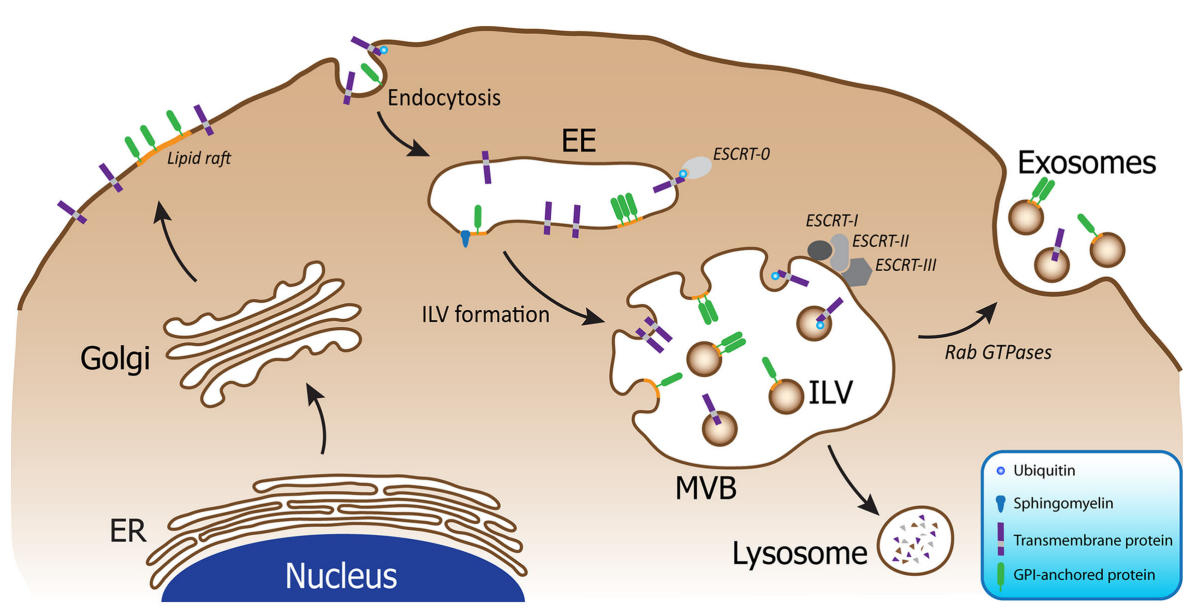

FIGURE 1 | Exosome biogenesis occurs within MVBs of the endosomal system. Following endocytosis into early endosomes (EE), the cargo is packaged into ILVs within MVBs upon inward budding of the membrane. Four different mechanisms have been described to facilitate this process: mono-ubiquitination and the ESCRT machinery; association with lipid rafts; higher-ordered oligomerization; and segregation into microdomains by ceramide. MVBs can then fuse with lysosomes resulting in degradation of the cargo, or alternatively, the MVBs can fuse with the plasma membrane, resulting in release of the ILVs as exosomes, a process which is regulated by Rab GTPases.
Simons and Raposo, 2009). The MVBs could vary in the amount of ILVs that are generated; the content of the ILVs; and also the ultimate fate of the ILVs, either targeted to lysosomes for degradation or released into the extracellular matrix as exosomes. The processes that govern the sorting of neurodegenerative disease related proteins into ILVs could therefore pre-determine the fate of these proteins, and thus play a role in disease progression. However, it is important to keep in mind that redundant pathways are a common phenomenon in biology, and therefore multiple mechanisms may be responsible for sorting various proteins into exosomes. Likewise sorting mechanisms involved may not be mutually exclusive and additional pathways could exist to compensate for disrupted pathways.

\section{THE ROLE OF EXOSOMES IN PRION AND ALZHEIMER'S DISEASES}

Prion diseases are fatal, transmissible neurodegenerative disorders that include CJD and Gerstmann-Straüssler-Scheinker Syndrome (GSS) in humans, bovine spongiform encephalopathy (BSE) in cattle and scrapie in sheep. In humans, prion disease occurs in sporadic, familial and acquired etiologies. However, all forms of the disease are transmissible, with possible routes of infection through dietary exposure, medical procedures, and blood transfusion (reviewed in Aguzzi and Heikenwalder, 2006). According to the protein-only hypothesis of prion propagation, an abnormal isoform of the cellular form of the prion protein $\left(\operatorname{PrP}^{\mathrm{C}}\right)$, which is referred to as $\mathrm{PrP}^{\mathrm{Sc}}$, is the sole or major component of the infectious prion agent (Prusiner, 1982). The normal prion protein isoform, $\operatorname{PrP}^{\mathrm{C}}$, is encoded by $P R N P$ and is expressed in all tissues of the human body, with the highest levels of expression observed in tissues of the central nervous system and brain.

Both $\mathrm{PrP}^{\mathrm{C}}$ and $\mathrm{PrP}^{\mathrm{Sc}}$ have been isolated in association with exosomes, and $\mathrm{PrP}^{\mathrm{Sc}}$ containing exosomes were infectious in both animal and cell bioassays (Fevrier et al., 2004; Vella et al., 2007; Alais et al., 2008). In addition, cells loaded with purified $\mathrm{PrP}^{\mathrm{Sc}}$ have been found to transfer between cells in vitro using tunneling nanotubes (Gousset et al., 2009). While tunneling nanotubes can traverse only short distances, exosomes are capable of traveling long distances, and are thus of interest in the peripheral spread of prions. Interestingly, a recent study found exosomes were able to traverse along tunneling nanotubes, suggesting many of these intercellular modes of transport may not be completely independent of one another (Mineo et al., 2012). Although these studies have primarily utilized cultured cell systems to isolate the exosomal vesicles, primary cultured neurons (Faure et al., 2006) and CSF (Vella et al., 2008) have also been used as a source of exosomes in which $\operatorname{PrP}^{\mathrm{C}}$ has been detected.

The exosome membrane contains lipid rafts enriched in cholesterol, sphingomyelin and ganglioside GM3 (Wubbolts et al., 2003) and externalized phosphatidylserine (Morelli et al., 2004) which are believed to participate in vesicle structure and function, and trafficking of particular proteins to exosomes (de Gassart et al., 2003). $\operatorname{PrP}^{\mathrm{C}}$ is tethered to the plasma membrane by a glycosylphosphatidyl-inositol (GPI) anchor, and the conversion of $\mathrm{PrP}^{\mathrm{C}}$ to $\mathrm{PrP}^{\mathrm{Sc}}$ has been suggested to occur in lipid raft regions (Taylor and Hooper, 2006). Additionally, an interaction between an N-terminal domain of PrP and a postulated lipid raft resident protein or lipid can occur on the membrane (Taylor and Hooper, 2006). GPI tethering is also likely to hold true in exosomes as phase partitioning experiments with Triton X-114 have shown that exosomal $\mathrm{PrP}^{\mathrm{C}}$ migrates to the detergent phase, consistent with it still containing a GPI anchor (Vella et al., 2007). The presence of lipid rafts in exosomes could also aid in its ability to transmit $\mathrm{PrP}^{\mathrm{Sc}}$. One study suggested that the generation of new $\mathrm{PrP}^{\mathrm{Sc}}$ during infection required the insertion of $\mathrm{PrP}^{\mathrm{Sc}}$ into lipid rafts (Baron et al., 2002). Hence it is plausible to speculate that the exosome containing $\mathrm{PrP}^{\mathrm{Sc}}$ may be able to insert its $\mathrm{PrP}^{\mathrm{Sc}}$ cargo into the membrane of recipient cells upon contact. Another function of the lipid raft nature of exosomes may be to stabilize a particular infectious isoform of $\mathrm{PrP}^{\mathrm{Sc}}$. Similar effects have been observed in cell free $\mathrm{PrP}$ 
conversion systems where lipids have been found to assist in the formation of de novo $\mathrm{PrP}^{\mathrm{Sc}}$, presumably by acting to stabilize or align intermediary isoforms (Deleault et al., 2007; Wang et al., 2007, 2010).

Alzheimer's disease $(\mathrm{AD})$ is the most common form of dementia in humans and is characterized pathologically by the extracellular deposition of insoluble amyloid plaques comprised of the $\beta$-amyloid peptide $(\mathrm{A} \beta)$, a 39-43 amino acid peptide produced by proteolytic cleavage of the amyloid precursor protein (APP; Cai et al., 1993; Findeis, 2000; Serpell and Smith, 2000; Murakami et al., 2002). The amyloidogenic pathway of APP processing involves sequential cleavage by $\beta$ - and $\gamma$-secretases. $\beta$-Secretase cleaves at the amino-terminus of A $\beta$ (Seubert et al., 1993; Mattson, 1997) resulting in the release of secreted APP, and leaves intact $A \beta$ as a membrane-associated, 99-amino-acid carboxy-terminal fragment $(\beta$-CTF). $\beta$-CTF can undergo endocytosis via clathrin-coated vesicles (Selkoe, 1996) and is trafficked to various endosomal compartments, including MVBs, from which exosomes are derived (Yamazaki et al., 1996). The initial link between A $\beta$ and its association with exosomes proposed that intracellular-accumulated $\mathrm{A} \beta$ in MVBs is incorporated into exosomes and released into the extracellular environment (Rajendran et al., 2006; Sharples et al., 2008). The identification of $A \beta$ in association with exosomes is an important finding, especially as other exosomal proteins such as Alix and Flotillin-1 have been found to accumulate in the plaques of brains from patients with AD (Rajendran et al., 2006). Exosomes could also provide an explanation for transport of $\mathrm{A} \beta$ and the equally toxic APP-CTFs around the body to the brain, where they contribute to amyloid deposition.

\section{PRION LIKE MECHANISMS IN OTHER NEURODEGENERATIVE DISEASES}

While prion diseases have long been thought to be the only neurodegenerative disease that is infectious and capable of spreading between individuals, key proteins involved in other neurodegenerative diseases such as Alzheimer's, Parkinson's and ALS may share similar behavioral features as prions (Table 1). At a basic biochemical level, misfolding and aggregation of these proteins can occur through seeded polymerization which has an initial, lengthy lag phase. However, this lag phase can be largely eliminated through the introduction of an already misfolded seed. Like prions, these aggregates appear to be able to persistently self-propagate, and there is also evidence of spreading from cell-to-cell and throughout the CNS. The spreading of these aggregates is no more obvious than when the neuropathology and deposition of the pathological proteins during these diseases is examined.

A considerable number of in vivo studies during the last half century have shown that prions from one diseased source can be introduced into an otherwise healthy animal and cause $\operatorname{Pr} \mathrm{P}^{\mathrm{Sc}}$ formation and clinical prion disease. However it wasn't until the mid-nineties when a similar experiment was conducted in which brain extracts from human Alzheimer's patients were injected into otherwise healthy primates and the formation of amyloid plaques was observed in the site of injection, and adjacent brain regions (Baker et al., 1994). These observations have since been reproduced in murine models of Alzheimer's disease (Kane et al., 2000; Meyer-Luehmann et al., 2006; Morales et al., 2011). Similarly, tau misfolding can be induced in transgenic mice by injection of tissue homogenates containing aggregated tau (Clavaguera et al., 2009). This phenomenon has also been observed in humans when patients with Parkinson's disease received grafts of normal neuronal stem cells. Upon post-mortem examination it was found that the grafts contained $\alpha$-synuclein inclusions that could only have arisen through transmission or spread from diseased brains (Kordower et al., 2008; Li et al., 2008). Interestingly, brain homogenates containing $\alpha$-synuclein aggregates, when injected into transgenic mice, were also found to be able to initiate both aggregation of $\alpha$-synuclein and the onset of clinical symptoms (Hansen et al., 2011). Given the intracellular origin of exosomes, they present a potential pathway in which cytosolic neurodegenerative disease related proteins are released into the extracellular space. In fact, a number of neurodegenerative disease related cytosolic proteins have already been found to be contained within exosomes such as $\alpha$-synuclein (Emmanouilidou et al., 2010; Alvarez-Erviti et al., 2011a) and tau (Saman et al., 2011). SOD1 has also been found released in association with exosomes from a cell model of ALS (Gomes et al., 2007).

Inoculation of permissive cell lines with brain homogenates from prion infected mice results in infection of cells with prions, and continual replication of $\mathrm{PrP}^{\mathrm{Sc}}$ that amplifies over time with increased passage of cells (Vella et al., 2007; Courageot et al., 2008; Vilette, 2008). Similar observations can be seen with other neurodegenerative diseases. Cultured neuronal cells incubated with tau aggregates were found to take up fibrils in an endocytic manner, and subsequently induce fibrillization of cytoplasmic tau (Frost et al., 2009; Guo and Lee, 2011). The newly aggregated intracellular tau was also capable of transferring between co-culture cells (Frost et al., 2009). Likewise polyglutamine peptide aggregates can also be taken up by cultured cells and sequestered into aggresomes, where they can recruit cytoplasmic proteins and transfer the aggregates between co-cultured cells (Ren et al., 2009). The application of exogenous recombinant aggregated $\alpha$-synuclein to cultured cells has also been found to be efficient at seeding aggregation of its intracellular counterpart, and subsequent transfer between cells by a number of groups (Danzer et al., 2009; Desplats et al., 2009; Hansen et al., 2011; Volpicelli-Daley et al., 2011).

Most recently, mutant SOD1 aggregates have been shown to be able to enter neuronal cells where they can seed aggregation of the normal, cytoplasmic mutant SOD1 (Munch et al., 2011). Upon removal of the seed, aggregation persists, suggesting these newly formed endogenous aggregates are capable of continually seeding further aggregation in a mechanism similar to $\mathrm{PrP}^{\mathrm{Sc}}$. Although it is unclear if exosome associated SOD1 is pathogenic, a mutant form of SOD1 was able to pass from cells through a $0.4 \mu \mathrm{m}$ filter and propagate in recipient cells (Munch et al., 2011). This suggests that mutant SOD1 aggregate seeds are less than $0.4 \mu \mathrm{m}$ and/or the aggregates are contained within exosomes. A similar experiment has been performed using these $0.4 \mu \mathrm{m}$ filters to demonstrate that $\mathrm{PrP}^{\mathrm{Sc}}$ can be transferred from one cell to another without direct cell contact, thus suggesting involvement of exosomes in this process (Alais et al., 2008).

Prion infectivity and seeding ability has been detected in the CSF of prion infected animals and humans (Atarashi et al., 2007, 2008, 2011; Wilham et al., 2010; Orru et al., 2012), and exosomes 
Bellingham et al.

Exosomes and neurodegenerative diseases

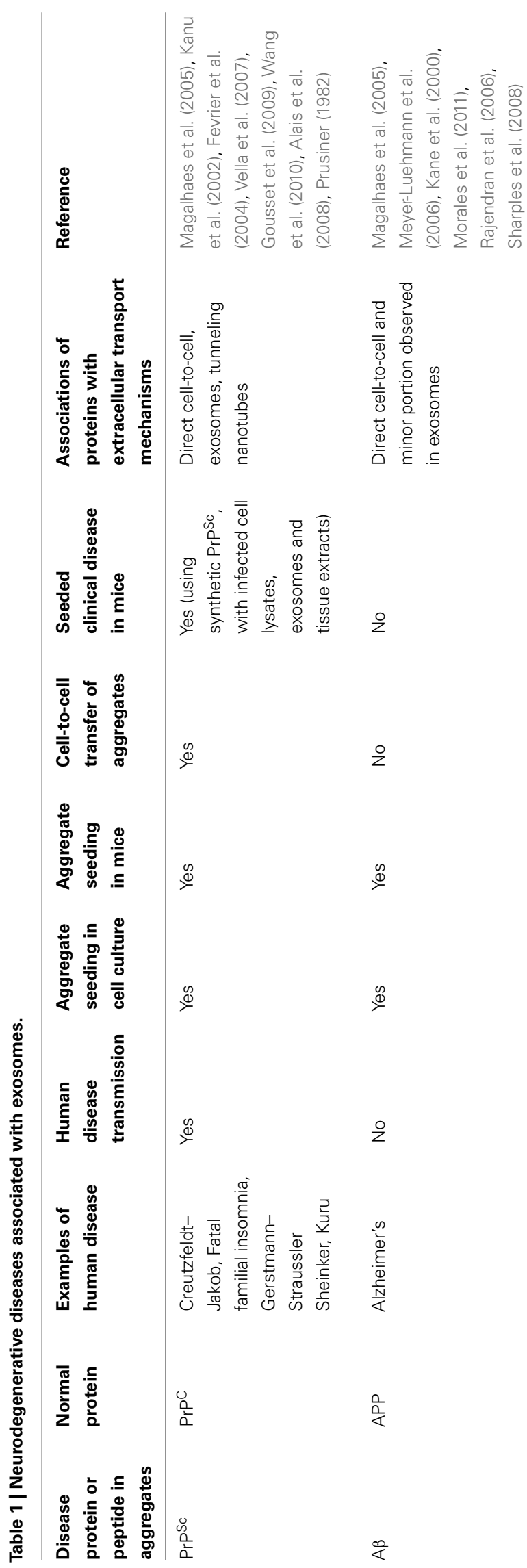

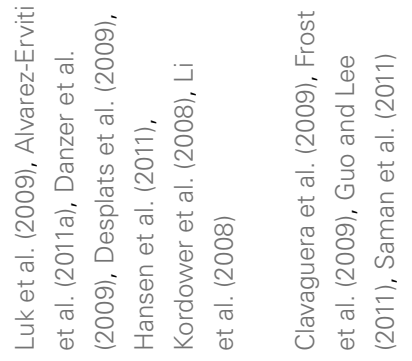

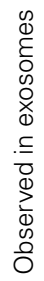

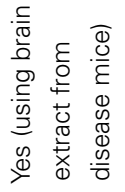

$\stackrel{\infty}{2}$

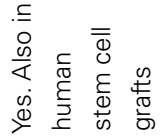

$\stackrel{\infty}{2}$

은

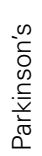

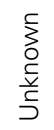

울

$\stackrel{\infty}{2}$

$\stackrel{\infty}{\infty}$

$\stackrel{\circ}{z}$

$\stackrel{\infty}{\infty}$ $\stackrel{\infty}{\longleftarrow}$

$\frac{5}{3}$

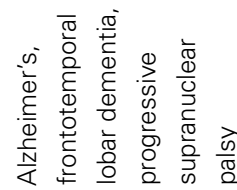

$\frac{\frac{c}{0}}{\frac{0}{0}}$

$\frac{\frac{c}{0}}{\frac{0}{0}}$

$\stackrel{\infty}{\infty}$

ํ.

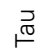

๑ே

oo

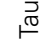

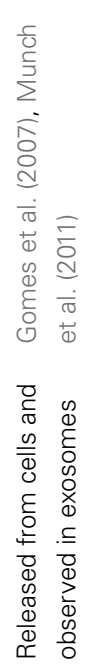

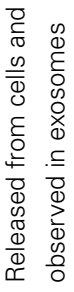

$\frac{c}{3}$
$\frac{c}{\frac{v}{c}}$
$\frac{5}{J}$
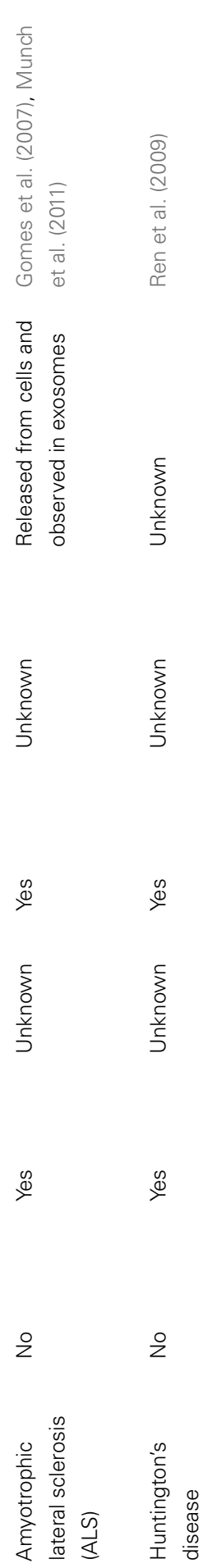

$\frac{5}{3}$
$\frac{5}{\frac{1}{c}}$
$\frac{5}{5}$

$\stackrel{\infty}{2}$

$\frac{\frac{5}{3}}{\frac{0}{\frac{1}{5}}}$

$\stackrel{\infty}{2}$

$\stackrel{ }{Z}$

등

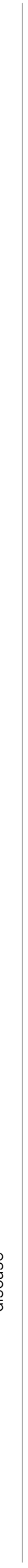

Frontiers in Physiology | Membrane Physiology and Biophysics

May 2012 | Volume 3 | Article 124 | 4 
isolated from sheep CSF are enriched in $\operatorname{PrP}^{\mathrm{C}}$ (Vella et al., 2008). Therefore it is plausible that some infectivity may be released into the CSF in association with exosomes in infected animals. Interestingly, exosomal markers were found to be enriched in amyloid plaques in the brains of mice (Kokubo et al., 2005) and postmortem human AD patients (Rajendran et al., 2006), suggesting exosomes played a role in trafficking of $A \beta$ aggregates to these sites during disease progression. Monomeric and oligomeric $\alpha$ synuclein and tau have also been found in blood and CSF in $\mathrm{PD}$ and AD patients (Vandermeeren et al., 1993; El-Agnaf et al., 2006; Tokuda et al., 2010; Bruggink et al., 2011), suggesting release from the CNS possibly in association with exosomes. Phosphorylated tau was also found in exosomes from human CSF in early Alzheimer's disease (Saman et al., 2011). Together, these observations provide strong evidence for the in vivo involvement of exosomes in neurodegenerative disease. While there is mounting evidence demonstrating exosomes maybe involved in the spread of pathogenic neurodegenerative disease related proteins, it is unknown whether they act purely as a transport mechanism or perhaps their structural and molecular makeup aid in the process.

\section{EXOSOME STRUCTURE AND FUNCTION IN NEURODEGENERATIVE PROTEIN TRANSFER}

Exosomes contain an array of different proteins; some are specific to the cell type of origin, while others are common across all exosomes. As a result of their endosomal origins exosomes contain proteins involved in membrane fusion and transport such as the Annexins and Rab proteins. Exosomes also contain heat shock proteins, adhesion molecules, metabolic enzymes, cytoskeletal proteins and are heavily enriched in tetraspanins such as CD63 and CD81 [as discussed in a number of reviews including (Thery et al., 2002; Schorey and Bhatnagar, 2008)] (Figure 2). It is suspected that proteins on the surface of exosomes aid in their uptake by recipient cells. Using proteases to shave off surface proteins of both exosomes and/or cells has been shown to reduce cellular uptake of exosomes (Escrevente et al., 2011), suggesting proteins on the surface of cells and exosomes act as mediators for facilitating fusion. It has also been shown that exosome transfer is inhibited at $4^{\circ} \mathrm{C}$ (Escrevente et al., 2011). These observations suggest exosome uptake is not a passive process, but is energy dependent and mediated by protein receptors.

Unlike the spread of prions via exosomes which need only surface interaction, transfer of the cytosolic neurodegenerative proteins into the recipient cells require the exogenous transporter exosomes to fuse with the plasma membrane. Direct fusion with the plasma membrane and release of contents into cytosol has been demonstrated with the use of luciferin-loaded exosomes which "injected" their intraluminal content into the cytosol of the target dendritic cells (Montecalvo et al., 2012). A similar mechanism is likely to occur when cationic liposomes were used to deliver $\alpha$-synuclein fibrils to cultured cells (Luk et al., 2009). The liposomes fused with the plasma membrane, delivering their exogenous $\alpha$-synuclein fibrils and induced formation of Lewy-body like structures in the cytoplasm of the recipient cell. Similarly, it was found that combining purified $\mathrm{PrP}^{\mathrm{Sc}}$ with microsomes or liposomes improved the efficiency of the $\mathrm{PrP}^{\mathrm{Sc}}$ as an inoculum in cell infections (Gabizon et al., 1988; Baron et al., 2006). Exosomes could potentially function in a similar manner to microsomes or liposomes by direct fusion with the plasma membrane improving the cellular uptake of prions or other neurodegenerative disease associated proteins. An alternative uptake mechanism of exosomes through endocytosis has been observed in rat neuronal PC12 cells with the endocytosed exosomes being trapped in cytosolic vesicles, and subsequently transported to the perinuclear region where they accumulate as large organelles (Tian et al., 2010). It is also possible that following endocytosis, back fusion can occur between the exosomal membrane and the limiting membrane of the endocytic compartment, thus releasing the exosomes luminal contents into the cytosol. Finally, aggregated proteins can damage lipid bilayers and form pores (Tsigelny et al., 2008) - a process which could occur post endocytosis releasing the misfolded proteins into the cytosol where they can seed further aggregation of the normal endogenous proteins.

\section{ROLE OF EXOSOMAL SHUTTLE RNA IN NEURODEGENERATIVE DISEASE}

Since their discovery, exosomes were thought to contain lipids and proteins with no genetic material (Johnstone et al., 1987). However, Ratajczak et al. (2006) reported that microvesicles, which are circular membrane vesicles $100-1000 \mathrm{~nm}$ shed directly from the plasma membrane, contained RNA. While Valadi et al. (2007) demonstrated that exosomes isolated from human and mouse mast cells contain both mRNA and miRNA, but no DNA. miRNA's are a class of non-coding RNA (ncRNA) species of approximately 22 nucleotides in length that function by post-translational repression of target mRNA's by binding to their $3^{\prime}$ untranslated regions (Bartel, 2004). Valadi et al. (2007) demonstrated that the exosomal RNA differed from that of donor cells from which they were derived, contained little or no ribosomal RNA and were enriched in small RNA species. Transfer experiments revealed that exosomal RNA is shuttled between donor and recipient mast cells and remained functional upon uptake in the recipient cell cytoplasm. Collectively these miRNA and mRNA species have been termed "exosomal shuttle RNA" (esRNA). esRNA was also shown to be contained and protected from degradation within the exosome vesicles themselves and it was proposed that exosome-mediated transfer of esRNA is a novel mechanism of genetic exchange between cells, either in the microenvironment or over a distance.

esRNA has since been isolated from exosomes derived from cancer cells, stem cells and dendritic cells (Taylor and GercelTaylor, 2008; Rabinowits et al., 2009); and biological fluids such as peripheral blood (Hunter et al., 2008), serum (Skog et al., 2008; Taylor and Gercel-Taylor, 2008), and saliva (Michael et al., 2010). Moreover, several studies have demonstrated a functional role of miRNA mediated transfer of exosomes to recipient cells (Valadi et al., 2007; Kosaka et al., 2010; Pegtel et al., 2010; Yang et al., 2011; Montecalvo et al., 2012). Tumor-suppressive miRNA's have been shown to be functional when transferred by exosomes in a ceramide dependent manner in prostate cancer cell lines (Kosaka et al., 2010). While immature and mature dendritic cells can package and release miRNA in exosomes dependent upon their activation state, with released exosomes fusing with recipient cell plasma membranes transferring functional miRNA into the cytosol (Montecalvo et al., 2012). Macrophages can also regulate 


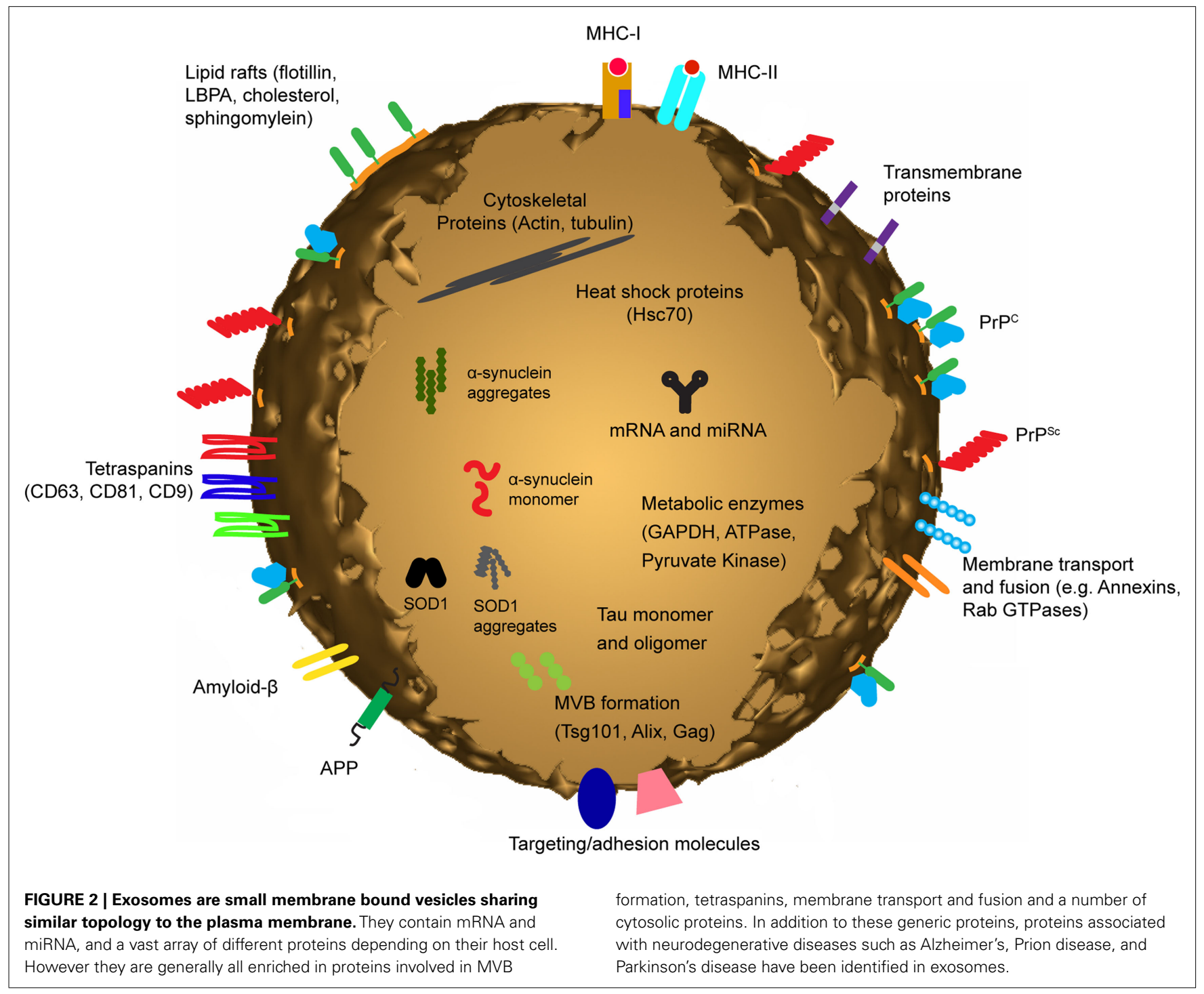

the invasiveness of breast cancer through exosome-mediated delivery of miRNA into cells promoting metastasis (Yang et al., 2011). Exosomes can also functionally deliver ncRNA, retroviral RNA repeats and tRNA sequences which are subsequently incorporated into RNA-silencing pathways (Gibbings et al., 2009; Lee et al., 2009; Haussecker et al., 2010). Likewise, tumor microvesicles have been demonstrated to contain elevated levels of specific coding, ncRNA and retrotransposon RNA transcripts from endogenous retroviruses that could be horizontally transferred during cancer progression (Balaj et al., 2011). These observations suggest that exosomes package and functionally deliver genetic components such as mature miRNA, mRNA, ncRNA, and retroviral RNA to the microenvironment, strongly supporting the role of exosomes in gene regulation mechanisms and intercellular communication.

Exosomes have been described to be released from a variety of neuronal cells types including microglial cells (Potolicchio et al., 2005), developing neurons (Faure et al., 2006), cultured astrocytes (Taylor et al., 2007), and oligodendrocytes (Kramer-Albers et al., 2007). Additionally, they have been shown to play a role in the normal physiology and synaptic plasticity of the central nervous system, with secretion of exosomes being regulated by calcium influx and glutamatergic synaptic activity in cortical and hippocampal neurons (Lachenal et al., 2011). Therefore, it is plausible to suggest that functional transfer of esRNA plays a significant yet uncharacterized role in the progression of neurodegenerative disorders such as Prion diseases, Alzheimer's disease, and other related disorders.

The nervous system is a rich source of miRNA expression, with estimates suggesting that neuronal miRNA's can posttranscriptionally modulate the expression of more than a third of the coding mRNAs (Kosik, 2006). While the functions of many discovered miRNA's so far remain unknown, some miRNA's have been shown to play a role in several biological processes including proliferation, organ development, cell differentiation, apoptosis, and infectious disease (Croce and Calin, 2005). The role of deregulated miRNA has also been implicated in cancer, with evidence suggesting that aberrant miRNA expression can function both as tumor suppressors and oncogenes (Esquela-Kerscher and Slack, 
2006). Aberrant miRNA expression has also been identified as a factor in neurodegenerative related disorders (reviewed in Hebert and De Strooper, 2007, 2009); with Table 2 summarizing miRNA's implicated in Prion diseases, Alzheimer's disease, Parkinson's, and Tauopathies.

In Alzheimer's disease, miRNA's have been shown to target the $3^{\prime}$ UTR of several key genes by regulating the expression and function of APP and BACE (the enzyme responsible for $\beta$-secretase cleavage of APP) in cell culture models of AD (Hebert et al., 2008, 2009; Patel et al., 2008; Boissonneault et al., 2009; Vilardo et al., 2010; Long and Lahiri, 2011). Extensive studies on post-mortem human $\mathrm{AD}$ brain samples and in transgenic $\mathrm{AD}$ mouse models also identified several miRNA that are significantly deregulated during the disease process (Lukiw and Pogue, 2007; Sethi and Lukiw, 2009; Nelson and Wang, 2010; Schonrock et al., 2010, 2012; Shioya et al., 2010; Li et al., 2011; Wang et al., 2011; Lukiw and Alexandrov, 2012).

Deregulated miRNA expression has also been suggested as a mechanism for failure of proteosomal degradation of insolubleand phosphorylated-tau proteins in tauopathies (Carrettiero et al., 2009), while a number of brain miRNA's have been shown to regulate the ratio of tau 3-repeat and 4-repeat isoforms causing progressive supranuclear palsy (Smith et al., 2011; Wanet et al., 2012). Interestingly genetic ablation of Dicer, which is responsible for mature miRNA biogenesis, in adult forebrain neurons results in hyperphosphorylation of tau, neuronal loss in the hippocampus, and cellular shrinkage in the cortex (Hebert et al., 2010). The hyperphosphorylation of tau was subsequently demonstrated to involve up-regulation of ERK kinases by deregulation of miR-15 in AD brains (Hebert et al., 2010).

Downregulation of miRNA's $133 \mathrm{~b}$ and miR-34b/34c has been demonstrated in Parkinson's disease mid-brain dopaminergic neurons (Kim et al., 2007; Minones-Moyano et al., 2011), while miR-7 and miR-153 can regulate expression of $\alpha$-synuclein $3^{\prime}$ UTR (Junn et al., 2009; Doxakis, 2010). Moreover, pathogenic LRRK2 can cause familial as well as sporadic Parkinson's disease characterized by age-dependent degeneration of dopaminergic neurons, possibly due to inhibition of miR-7 mediated translational repression of $\alpha$-synuclein (Gehrke et al., 2010).

A miRNA signature in prion disease has been reported in prion infected mice and primates (Saba et al., 2008; Montag et al., 2009). Both studies examined the miRNA profile in brain tissue after clinical symptoms of disease were well-established and determined a subset of miRNA's to be significantly deregulated. In prion infected

Table 2 | Dysregulation of miRNA's in neurodegenerative diseases.

\begin{tabular}{|c|c|c|}
\hline $\begin{array}{l}\text { Neurodegenerative } \\
\text { disease }\end{array}$ & Deregulated miRNA & Reference \\
\hline \multirow[t]{3}{*}{ Prion diseases } & 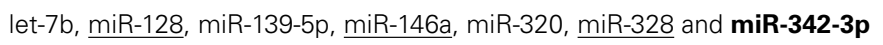 & Saba et al. (2008) \\
\hline & miR-342-3p and miR-494 & Montag et al. (2009) \\
\hline & $\underline{\operatorname{miR}-146 a}$ & Lukiw et al. (2011), Saba et al. (2012) \\
\hline \multirow[t]{13}{*}{ Alzheimer's disease } & $\underline{\operatorname{miR}-9}, \underline{\operatorname{miR}-124}, \underline{\operatorname{miR}-125 b}, \underline{\operatorname{miR}-128}, \underline{\operatorname{miR}-132}$ and miR-219 & Lukiw and Pogue (2007) \\
\hline & $\underline{\operatorname{miR}-9}, \mathbf{m i R - 2 9 a}$ and $\mathbf{m i R - 2 9 b}$ & Hebert et al. (2008) \\
\hline & $\overline{\mathrm{miR}-106 a}$ and miR-520c & Patel et al. (2008) \\
\hline & $\operatorname{miR}-107$ & Wang et al. (2008), Nelson and Wang (2010) \\
\hline & miR-298 and $\underline{\operatorname{miR}-328}$ & Boissonneault et al. (2009) \\
\hline & miR-17-5p, miR-20, and miR-106b & Hebert et al. (2009) \\
\hline & $\underline{\operatorname{miR}}-9, \underline{m i R}-125 b$ and $\underline{\operatorname{miR}}-146 a$ & Sethi and Lukiw (2009) \\
\hline & $\underline{\operatorname{miR}-146 a}$ & Li et al. (2011), Lukiw et al. (2011) \\
\hline & $\operatorname{miR}-101$ & Vilardo et al. (2010), Long and Lahiri (2011) \\
\hline & $\underline{\operatorname{miR}-9}$ and miR-191c & Schonrock et al. (2010), Schonrock et al. (2012) \\
\hline & miR-29a & Shioya et al. (2010) \\
\hline & $\underline{\operatorname{miR}-15}$, miR-107, miR-29a, miR-29b, miR-212, miR-424 & Wang et al. (2011) \\
\hline & miR-125b and $\underline{\operatorname{miR}-146 a}$ & Lukiw and Alexandrov (2012) \\
\hline \multirow[t]{5}{*}{ Parkinson's disease } & $\operatorname{miR}-133 b$ & Kim et al. (2007) \\
\hline & miR-7 & Junn et al. (2009) \\
\hline & miR-7 and miR-153 & Doxakis (2010) \\
\hline & miR-7 and miR-184* & Gehrke et al. (2010) \\
\hline & miR-34b and miR-34c & Minones-Moyano et al. (2011) \\
\hline \multirow[t]{4}{*}{ Tauopathies } & $\underline{\operatorname{miR}-128}$ & Carrettiero et al. (2009) \\
\hline & $\underline{\operatorname{miR}-15}$ & Hebert et al. (2010) \\
\hline & 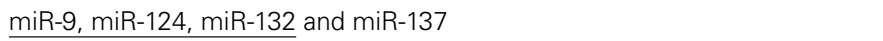 & Smith et al. (2011) \\
\hline & $\overline{\mathrm{miR}-132}$ and miR-212 & Wanet et al. (2012) \\
\hline
\end{tabular}

miRNA that has been shown to be deregulated in a number of neurodegenerative diseases are underlined.

miRNA deregulated in individual neurodegenerative disease and validated by independent studies are indicated in bold. 
mice, Saba et al. (2008) identified 15 miRNA's to be significantly deregulated upon prion infection including up-regulation of miR342-3p and miR-146a. miR-342-3p was also up-regulated in prion infected primate cynomolgus macaques and in brain tissue of type-1 and type-2 human sporadic CJD cases (Montag et al., 2009). Up-regulation of miR-146a during prion infection is proposed to involve inflammatory response pathways and correlates with deposition of prion plaques and activation of surrounding microglia (Saba et al., 2012). Up-regulated miR-146a was also observed in human neuronal-glial primary cell co-cultures challenged with five different species of single- or double-stranded DNA or RNA neurotrophic viruses, pro-inflammatory cytokines, $A \beta 42$ peptide, metal-induced neurotoxicity, and oxidative stress. Furthermore, miR-146a up-regulation was also observed in murine scrapie, in $\mathrm{AD}$ brains, and rare human prion disorders, including sporadic CJD and GSS (Lukiw et al., 2011). These results suggest that miR146a up-regulation in human brain cells is a general mechanism of innate immune response and antiviral immunity (Lukiw et al., 2011).

Despite the increasing body of evidence implicating dysregulated miRNA expression in a number of neurodegenerative disorders and exosomes are implicated in the pathogenic transfer of neurotoxic proteins in these diseases, very little research has focused on the potential role of esRNA in pathogenesis and diagnosis of neurological diseases. Given that several studies have successfully identified miRNA profiles from circulating exosomes isolated from plasma and serum samples in the diagnosis of human diseases including ovarian cancer, glioblastoma, and lung adenocarcinoma (Skog et al., 2008; Taylor and Gercel-Taylor, 2008; Rabinowits et al., 2009), then it is plausible to suggest that miRNA profiling can be applied to diagnosis in other diseases. Recently, it has been reported that extracellular miRNA released from cells in plasma can associate in two populations, both dependent and independent of exosomes either bound to AGO2 (Arroyo et al., 2011; Turchinovich et al., 2011) or high-density lipoproteins (Vickers et al., 2011). Therefore, targeted exosomal purification strategies for enrichment of circulating miRNA biomarkers may be required to increase biomarker sensitivity. Moreover, circulating exosomes isolated for the study of Prion, Alzheimer's, Parkinson's, and other related disorders represent a unique subset of exosomal populations that can be enriched by targeting the defined toxic protein biomarkers associated with these disorders. This strategy can then be coupled to small RNA next generation sequencing technologies to accurately determine circulating exosomal miRNA signatures specific to individual diseases.

\section{POTENTIAL OF EXOSOMES IN NEURODEGENERATIVE DISEASE THERAPEUTICS?}

With the discovery that exosomes are able to transmit protein, mRNA and miRNA between cells, the possibility arose that exosomes could be exploited as vehicles for delivering therapeutic compounds in vivo (Valadi et al., 2007; Simons and Raposo, 2009; Sun et al., 2010). Since the development of RNA interference (RNAi), much work has been carried out to utilize this technology for treatment of various diseases. However, many barriers were encountered, plaguing clinical translation of this technology. One of the biggest issues faced is the ability to target specific tissues and at therapeutic doses without eliciting immune responses and inducing toxicity (van den Boorn et al., 2011). Current approaches for clinical application of RNAi include usage of viral and synthetic carrier systems such as liposomes and nanoparticles. However, there are several disadvantages with these systems. Viral particles can be cleared from the body by antibodies and also has the potential to activate immune responses, making repeated administration challenging (Waehler et al., 2007). Harnessing exosomes, the body's own intercellular delivery mechanism, would therefore provide a breakthrough for the field of drug delivery and it would bypass many issues such as immune activation, acceptance by target cells, and prevent degradation of cargo.

In a recent study, the first steps toward the application of exosomes as a drug delivery vehicle was taken. Using exosomes from immature murine dendritic cells, Alvarez-Erviti et al. (2011b) modified the exosomes to express a fusion of the exosomal membrane protein Lamp2b and a neuron-specific RVG peptide. The exosomes were then loaded with siRNA for BACE1, a protein implicated in Alzheimer's disease. Following intravenous injection, the exosomes were targeted to the neurons, microglia and oligodendrocytes in the mouse brain, and was able to induce knockdown of BACE1. This discovery highlighted the therapeutic potential of exosome-mediated RNAi technology, with possible applications in neurodegenerative diseases, such as prion disease and Alzheimer's disease, where the key mediators of these diseases can be targeted for knockdown using this approach.

Despite the appeal, in order to apply this technology clinically, a few issues still need to be addressed. Firstly, a stable source of well characterized exosomes that can be expanded needs to be established (van Dommelen et al., 2011). The process of loading exosomes with siRNA will also require optimization in order to achieve maximum efficiency and reduce the need to administer large amounts of exosomes during therapy. Tissue-specific targeting of exosomes should also be further refined to ensure both a safe and specific delivery to target tissues, as well as efficient diffusion across the blood brain barrier. With further improvements in techniques and technology, exosomes hold great potential to revolutionize RNAi-mediated therapy, opening up a door to an alternative, untapped source of clinical therapy.

The precise mechanisms that govern the packaging of esRNA inside exosomes remain unanswered. While several potential mechanisms can be postulated, the most logical explanation is that RNA is packaged directly from the cytoplasm as a result of initial invagination of the MVB into ILV's. However, several studies have shown that exosomes contain little or no $18 \mathrm{~S}$ and $28 \mathrm{~S}$ cellular ribosomal species; not all mRNA and miRNA contained within cells can be detected in exosomes, and that some mRNA and miRNA can be directly targeted and packaged in exosomes (Valadi et al., 2007; Hunter et al., 2008; Taylor and Gercel-Taylor, 2008; Pigati et al., 2010; Montecalvo et al., 2012). These observations suggest that esRNA is selectively incorporated into ILV's as opposed to random events or contamination during the process of exosome isolation.

\section{CONCLUSION}

As exosomes are being associated with an increasing number of neurodegenerative disorders they may provide a source 
of both protein and genetic biomarkers obtained from circulating exosomes, as well as new insights into the observed spreading of neuropathologic lesions common to these diseases. One current drawback of using exosomes for biomarker discovery is the methods that are used for their isolation (based on ultracentrifugation and filtration) as these methods are not immediately amenable for high-throughput screening. The identification of esRNA in exosomes provides an attractive target for biomarkers as demonstrated by the studies in brain tumors. Applying the genetic analysis of exosomes from neurodegenerative disorders such as prion diseases and $\mathrm{AD}$ may

\section{REFERENCES}

Aguzzi, A., and Heikenwalder, M. (2006). Pathogenesis of prion diseases: current status and future outlook. Nat. Rev. Microbiol. 4, 765-775.

Alais, S., Simoes, S., Baas, D., Lehmann, S., Raposo, G., Darlix, J. L., and Leblanc, P. (2008). Mouse neuroblastoma cells release prion infectivity associated with exosomal vesicles. Biol. Cell 100, 603-615.

Alvarez-Erviti, L., Seow, Y., Schapira, A. H., Gardiner, C., Sargent, I. L., Wood, M. J., and Cooper, J. M. (2011a). Lysosomal dysfunction increases exosome-mediated alphasynuclein release and transmission. Neurobiol. Dis. 42, 360-367.

Alvarez-Erviti, L., Seow, Y. Q., Yin, H. F., Betts, C., Lakhal, S., and Wood, M. J. A. (2011b). Delivery of siRNA to the mouse brain by systemic injection of targeted exosomes. Nat. Biotechnol. 29, 341-U179.

Arroyo, J. D., Chevillet, J. R., Kroh, E. M., Ruf, I. K., Pritchard, C. C., Gibson, D. F., Mitchell, P. S., Bennett, C. F., Pogosova-Agadjanyan, E. L., Stirewalt, D. L., Tait, J. F., and Tewari, M. (2011). Argonaute2 complexes carry a population of circulating microRNAs independent of vesicles in human plasma. Proc. Natl. Acad. Sci. U.S.A. 108, 5003-5008.

Atarashi, R., Moore, R. A., Sim, V. L., Hughson, A. G., Dorward, D. W., Onwubiko, H. A., Priola, S. A., and Caughey, B. (2007). Ultrasensitive detection of scrapie prion protein using seeded conversion of recombinant prion protein. Nat. Methods 4, 645-650.

Atarashi, R., Sano, K., Satoh, K., and Nishida, N. (2011). Realtime quaking-induced conversion: a highly sensitive assay for prion detection. Prion 5, 150-153.

Atarashi, R., Wilham, J. M., Christensen, L., Hughson, A. G., Moore, R. A., Johnson, L. M., Onwubiko, H. A., Priola, S. A., and Caughey, B. (2008). Simplified ultrasensitive prion detection by recombinant $\operatorname{PrP}$ conversion with shaking. Nat. Methods 5, 211-212.

Baker, H. F., Ridley, R. M., Duchen, L. W., Crow, T. J., and Bruton, C. J. (1994). Induction of beta (A4)-amyloid in primates by injection of Alzheimer's disease brain homogenate. Comparison with transmission of spongiform encephalopathy. Mol. Neurobiol. 8, 25-39.

Balaj, L., Lessard, R., Dai, L., Cho, Y. J., Pomeroy, S. L., Breakefield, X. O., and Skog, J. (2011). Tumour microvesicles contain retrotransposon elements and amplified oncogene sequences. Nat. Commun. 2, 180.

Baron, G. S., Magalhaes, A. C., Prado, M. A., and Caughey, B. (2006). Mouse-adapted scrapie infection of SN56 cells: greater efficiency with microsome-associated versus purified PrP-res. J. Virol. 80, 2106-2117.

Baron, G. S., Wehrly, K., Dorward, D. W., Chesebro, B., and Caughey, B. (2002). Conversion of raft associated prion protein to the proteaseresistant state requires insertion of $\operatorname{PrP}-$ res $(\operatorname{PrP}(\mathrm{Sc}))$ into contiguous membranes. $Е M B O$ J. 21, 1031-1040.

Bartel, D. P. (2004). MicroRNAs: genomics, biogenesis, mechanism, and function. Cell 116, 281-297.

Boissonneault, V., Plante, I., Rivest, S., and Provost, P. (2009). MicroRNA298 and microRNA-328 regulate expression of mouse beta-amyloid precursor protein-converting enzyme 1. J. Biol. Chem. 284, 1971-1981.

Bruggink, K. A., Kuiperij, H. B., Ekholm-Pettersson, F., and Verbeek, M. M. (2011). Detection of elevated levels of alpha-synuclein oligomers in CSF from patients with Parkinson disease. Neurology 77, 510-511.

Cai, X., Golde, T. E., and Younkin, S. G. (1993). Release of excess amyloid $b$ protein from a mutant amyloid b protein precursor. Science 259, 514-516.

identify suitable biomarkers that are applicable for diagnostic applications.

\section{ACKNOWLEDGMENTS}

Shayne A. Bellingham is supported by a National Health and Medical Research Council (NHMRC) Early Career Fellowship; Belinda B. Guo is supported by an Australian Postgraduate Award; Bradley M. Coleman is supported by an NHMRC Dora Lush Postgraduate Scholarship and Andrew F. Hill is supported by an Australian Research Council (www.arc.gov.au) Future Fellowship (ID:FT100100560).

Carrettiero, D. C., Hernandez, I., Neveu, P., Papagiannakopoulos, T., and Kosik, K. S. (2009). The cochaperone BAG2 sweeps paired helical filament- insoluble tau from the microtubule. J. Neurosci. 29, 2151-2161.

Clavaguera, F., Bolmont, T., Crowther, R. A., Abramowski, D., Frank, S., Probst, A., Fraser, G., Stalder, A. K. Beibel, M., Staufenbiel, M., Jucker, M., Goedert, M., and Tolnay, M. (2009). Transmission and spreading of tauopathy in transgenic mouse brain. Nat. Cell Biol. 11, 909-913.

Courageot, M. P., Daude, N., Nonno, R., Paquet, S., Di Bari, M. A., Le Dur, A., Chapuis, J., Hill, A. F., Agrimi, U., Laude, H., and Vilette, D. (2008). A cell line infectible by prion strains from different species. J. Gen. Virol. 89, 341-347.

Croce, C. M., and Calin, G. A. (2005). miRNAs, cancer, and stem cell division. Cell 122, 6-7.

Danzer, K. M., Krebs, S. K., Wolff, M., Birk, G., and Hengerer, B. (2009). Seeding induced by alphasynuclein oligomers provides evidence for spreading of alphasynuclein pathology. J. Neurochem. 111, 192-203.

de Gassart, A., Geminard, C., Fevrier, B., Raposo, G., and Vidal, M. (2003). Lipid raft-associated protein sorting in exosomes. Blood 102, 4336-4344.

Deleault, N. R., Harris, B. T., Rees, J. R., and Supattapone, S. (2007). From the cover: formation of native prions from minimal components in vitro. Proc. Natl. Acad. Sci. U.S.A. 104, 9741-9746.

Desplats, P., Lee, H. J., Bae, E. J., Patrick, C., Rockenstein, E., Crews, L., Spencer, B., Masliah, E., and Lee, S. J. (2009). Inclusion formation and neuronal cell death through neuron-to-neuron transmission of alpha-synuclein. Proc. Natl. Acad. Sci. U.S.A. 106, 13010-13015.

Doxakis, E. (2010). Post-transcriptional regulation of alpha-synuclein expression by mir-7 and mir-153. J. Biol. Chem. 285, 12726-12734.
El-Agnaf, O. M., Salem, S. A., Paleologou, K. E., Curran, M. D., Gibson, M. J., Court, J. A., Schlossmacher, M. G., and Allsop, D. (2006). Detection of oligomeric forms of alpha-synuclein protein in human plasma as a potential biomarker for Parkinson's disease. FASEB J. 20, 419-425.

Emmanouilidou, E., Melachroinou, K., Roumeliotis, T., Garbis, S. D. Ntzouni, M., Margaritis, L. H., Stefanis, L., and Vekrellis, K. (2010). Cell-produced alpha-synuclein is secreted in a calcium-dependent manner by exosomes and impacts neuronal survival. J. Neurosci. 30, 6838-6851.

Escrevente, C., Keller, S., Altevogt, P., and Costa, J. (2011). Interaction and uptake of exosomes by ovarian cancer cells. BMC Cancer 11, 108. doi:10.1186/1471-2407-11-108

Esquela-Kerscher, A., and Slack, F. J. (2006). Oncomirs - microRNAs with a role in cancer. Nat. Rev. Cancer 6, 259-269.

Fang, Y., Wu, N., Gan, X., Yan, W., Morrell, J. C., and Gould, S. J. (2007). Higher-order oligomerization targets plasma membrane proteins and HIV gag to exosomes. PLoS Biol. 5, e158. doi:10.1371/journal.pbio.0050158

Faure, J., Lachenal, G., Court, M., Hirrlinger, J., Chatellard-Causse, C., Blot, B., Grange, J., Schoehn, G., Goldberg, Y., Boyer, V., Kirchhoff, F., Raposo, G., Garin, J., and Sadoul, R. (2006). Exosomes are released by cultured cortical neurones. Mol. Cell. Neurosci. 31, 642-648.

Fevrier, B., Vilette, D., Archer, F., Loew, D., Faigle, W., Vidal, M., Laude, H., and Raposo, G. (2004). Cells release prions in association with exosomes. Proc. Natl. Acad. Sci. U.S.A. 101, 9683-9688.

Findeis, M. A. (2000). Approaches to discovery and characterization of inhibitors of amyloid b-peptide polymerization. Biochim. Biophys. Acta 1502, 76-84. 
Frost, B., Jacks, R. L., and Diamond, M. I. (2009). Propagation of tau misfolding from the outside to the inside of a cell. J. Biol. Chem. 284, 12845-12852.

Gabizon, R., Mckinley, M. P., Groth, D. F., Kenaga, L., and Prusiner, S. B. (1988). Properties of scrapie prion protein liposomes. J. Biol. Chem. 263, 4950-4955.

Gehrke, S., Imai, Y., Sokol, N., and Lu, B. (2010). Pathogenic LRRK2 negatively regulates microRNA-mediated translational repression. Nature 466, 637-641.

Gibbings, D. J., Ciaudo, C., Erhardt, M., and Voinnet, O. (2009). Multivesicular bodies associate with components of miRNA effector complexes and modulate miRNA activity. Nat. Cell Biol. 11, 1143-1149.

Gomes, C., Keller, S., Altevogt, P., and Costa, J. (2007). Evidence for secretion of $\mathrm{Cu}, \mathrm{Zn}$ superoxide dismutase via exosomes from a cell model of amyotrophic lateral sclerosis. Neurosci. Lett. 428, 43-46.

Gousset, K., Schiff, E., Langevin, C., Marijanovic, Z., Caputo, A., Browman, D. T., Chenouard, N., De Chaumont, F., Martino, A., Enninga, J., Olivo-Marin, J. C., Mannel, D., and Zurzolo, C. (2009). Prions hijack tunnelling nanotubes for intercellular spread. Nat. Cell Biol. 11, 328-336.

Guo, J. L., and Lee, V. M. (2011). Seeding of normal Tau by pathological Tau conformers drives pathogenesis of Alzheimer-like tangles. J. Biol. Chem. 286, 15317-15331.

Hansen, C., Angot, E., Bergstrom, A. L., Steiner, J. A., Pieri, L., Paul, G., Outeiro, T. F., Melki, R., Kallunki, P., Fog, K., Li, J. Y., and Brundin, P. (2011). alpha-Synuclein propagates from mouse brain to grafted dopaminergic neurons and seeds aggregation in cultured human cells. J. Clin. Invest. 121, 715-725.

Haussecker, D., Huang, Y., Lau, A., Parameswaran, P., Fire, A. Z., and Kay, M. A. (2010). Human tRNA-derived small RNAs in the global regulation of RNA silencing. RNA 16, 673-695.

Hebert, S. S., and De Strooper, B. (2007). Molecular biology. miRNAs in neurodegeneration. Science 317, 1179-1180.

Hebert, S. S., and De Strooper, B. (2009). Alterations of the microRNA network cause neurodegenerative disease. Trends Neurosci. 32, 199-206.

Hebert, S. S., Horre, K., Nicolai, L., Bergmans, B., Papadopoulou, A. S., Delacourte, A., and De Strooper, B. (2009). MicroRNA regulation of
Alzheimer's Amyloid precursor protein expression. Neurobiol. Dis. 33, 422-428.

Hebert, S. S., Horre, K., Nicolai, L., Papadopoulou, A. S., Mandemakers, W., Silahtaroglu, A. N., Kauppinen, S., Delacourte, A., and De Strooper, B. (2008). Loss of microRNA cluster miR-29a/b-1 in sporadic Alzheimer's disease correlates with increased BACE1/betasecretase expression. Proc. Natl. Acad. Sci. U.S.A. 105, 6415-6420.

Hebert, S. S., Papadopoulou, A. S., Smith, P., Galas, M. C., Planel, E., Silahtaroglu, A. N., Sergeant, N., Buee, L., and De Strooper, B. (2010). Genetic ablation of Dicer in adult forebrain neurons results in abnormal tau hyperphosphorylation and neurodegeneration. Hum. Mol. Genet. 19, 3959-3969.

Hicke, L. (2001). Protein regulation by monoubiquitin. Nat. Rev. Mol. Cell Biol. 2, 195-201.

Hunter, M. P., Ismail, N., Zhang, X., Aguda, B. D., Lee, E. J., Yu, L., Xiao, T., Schafer, J., Lee, M. L., Schmittgen, T. D., Nana-Sinkam, S. P., Jarjoura, D., and Marsh, C. B. (2008). Detection of microRNA expression in human peripheral blood microvesicles. PLoS ONE 3, e3694. doi:10.1371/journal.pone.0003694

Johnstone, R. M., Adam, M., Hammond, J. R., Orr, L., and Turbide, C. (1987). Vesicle formation during reticulocyte maturation. Association of plasma membrane activities with released vesicles (exosomes). J. Biol. Chem. 262, 9412-9420.

Junn, E., Lee, K. W., Jeong, B. S., Chan, T. W., Im, J. Y., and Mouradian, M. M. (2009). Repression of alphasynuclein expression and toxicity by microRNA-7. Proc. Natl. Acad. Sci. U.S.A. 106, 13052-13057.

Kane, M. D., Lipinski, W. J., Callahan, M. J., Bian, F., Durham, R. A., Schwarz, R. D., Roher, A. E., and Walker, L. C. (2000). Evidence for seeding of beta-amyloid by intracerebral infusion of Alzheimer brain extracts in beta-amyloid precursor protein-transgenic mice. J. Neurosci. 20, 3606-3611.

Kanu, N., Imokawa, Y., Drechsel, D. N., Williamson, R. A., Birkett, C. R., Bostock, C. J., and Brockes, J. P. (2002). Transfer of scrapie prion infectivity by cell contact in culture. Curr. Biol. 12, 523-530.

Kim, J., Inoue, K., Ishii, J., Vanti, W. B., Voronov, S. V., Murchison, E., Hannon, G., and Abeliovich, A. (2007). A MicroRNA feedback circuit in midbrain dopamine neurons. Science $317,1220-1224$.
Kokubo, H., Saido, T. C., Iwata, N., Helms, J. B., Shinohara, R., and Yamaguchi, H. (2005). Part of membrane-bound Abeta exists in rafts within senile plaques in Tg2576 mouse brain. Neurobiol. Aging 26, 409-418.

Kordower, J. H., Chu, Y., Hauser, R. A., Freeman, T. B., and Olanow, C. W. (2008). Lewy body-like pathology in long-term embryonic nigral transplants in Parkinson's disease. Nat. Med. 14, 504-506.

Kosaka, N., Iguchi, H., Yoshioka, Y., Takeshita, F., Matsuki, Y., and Ochiya, T. (2010). Secretory mechanisms and intercellular transfer of microRNAs in living cells. J. Biol. Chem. 285, 17442-17452.

Kosik, K. S. (2006). The neuronal microRNA system. Nat. Rev. Neurosci. 7, 911-920.

Kramer-Albers, E. M., Bretz, N., Tenzer, S., Winterstein, C., Mobius, W., Berger, H., Nave, K. A., Schild, H., and Trotter, J. (2007). Oligodendrocytes secrete exosomes containing major myelin and stress-protective proteins: trophic support for axons? Proteomics Clin. Appl. 1, 1446-1461.

Lachenal, G., Pernet-Gallay, K., Chivet, M., Hemming, F. J., Belly, A., Bodon, G., Blot, B., Haase, G., Goldberg, Y., and Sadoul, R. (2011). Release of exosomes from differentiated neurons and its regulation by synaptic glutamatergic activity. Mol. Cell. Neurosci. 46, 409-418.

Lee, Y. S., Shibata, Y., Malhotra, A. and Dutta, A. (2009). A novel class of small RNAs: tRNA-derived RNA fragments (tRFs). Genes Dev. 23, 2639-2649.

Li, J. Y., Englund, E., Holton, J. L., Soulet, D., Hagell, P., Lees, A. J., Lashley, T., Quinn, N. P., Rehncrona, S., Bjorklund, A., Widner, H., Revesz, T., Lindvall, O., and Brundin, P. (2008). Lewy bodies in grafted neurons in subjects with Parkinson's disease suggest host-to-graft disease propagation. Nat. Med. 14, 501-503.

Li, Y. Y., Cui, J. G., Hill, J. M., Bhattacharjee, S., Zhao, Y., and Lukiw, W. J. (2011). Increased expression of miRNA-146a in Alzheimer's disease transgenic mouse models. Neurosci. Lett. 487, 94-98.

Long, J. M., and Lahiri, D. K (2011). MicroRNA-101 downregulates Alzheimer's amyloid-beta precursor protein levels in human cell cultures and is differentially expressed. Biochem. Biophys. Res. Commun. 404, 889-895.

Luk, K. C., Song, C., O’Brien, P., Stieber, A., Branch, J. R., Brunden, K. R., Trojanowski, J. Q., and Lee, V. M.
(2009). Exogenous alpha-synuclein fibrils seed the formation of Lewy body-like intracellular inclusions in cultured cells. Proc. Natl. Acad. Sci. U.S.A. 106, 20051-20056.

Lukiw, W. J., and Alexandrov, P. N. (2012). Regulation of complement factor $\mathrm{H}(\mathrm{CFH})$ by multiple miRNAs in Alzheimer's disease (AD) brain. Mol. Neurobiol. doi: 10.1007/s12035012-8234-4

Lukiw, W. J., Dua, P., Pogue, A. I., Eicken, C., and Hill, J. M. (2011). Upregulation of micro RNA-146a (miRNA-146a), a marker for inflammatory neurodegeneration, in sporadic Creutzfeldt-Jakob disease (sCJD) and Gerstmann-StrausslerScheinker (GSS) syndrome. J. Toxicol. Environ. Health Part A 74, 1460-1468.

Lukiw, W. J., and Pogue, A. I. (2007). Induction of specific micro RNA (miRNA) species by ROS-generating metal sulfates in primary human brain cells. J. Inorg. Biochem. 101, 1265-1269.

Magalhaes, A. C., Baron, G. S., Lee, K. S., Steele-Mortimer, O., Dorward, D., Prado, M. A., and Caughey, B. (2005). Uptake and neuritic transport of scrapie prion protein coincident with infection of neuronal cells. J. Neurosci. 25, 5207-5216.

Mattson, M. P. (1997). Cellular actions of b-amyloid precursor protein and its soluble and fibrillogenic derivatives [review]. Physiol. Rev. 77, 1081-1132.

Meyer-Luehmann, M., Coomaraswamy, J., Bolmont, T., Kaeser, S., Schaefer, C., Kilger, E., Neuenschwander, A., Abramowski, D., Frey, P., Jaton, A. L., Vigouret, J. M., Paganetti, P., Walsh, D. M., Mathews, P. M., Ghiso, J., Staufenbiel, M., Walker, L. C., and Jucker, M. (2006). Exogenous induction of cerebral beta-amyloidogenesis is governed by agent and host. Science 313, 1781-1784.

Michael, A., Bajracharya, S. D., Yuen, P. S., Zhou, H., Star, R. A., Illei, G. G., and Alevizos, I. (2010). Exosomes from human saliva as a source of microRNA biomarkers. Oral. Dis. 16, 34-38.

Mineo, M., Garfield, S. H., Taverna, S., Flugy, A., De Leo, G., Alessandro, R., and Kohn, E. C. (2012). Exosomes released by $\mathrm{K} 562$ chronic myeloid leukemia cells promote angiogenesis in a src-dependent fashion. Angiogenesis 15, 33-45.

Minones-Moyano, E., Porta, S., Escaramis, G., Rabionet, R., Iraola, S., Kagerbauer, B., Espinosa-Parrilla, Y., Ferrer, I., Estivill, X., and Marti, 
E. (2011). MicroRNA profiling of Parkinson's disease brains identifies early downregulation of miR-34b/c which modulate mitochondrial function. Hum. Mol. Genet. 20, 3067-3078.

Montag, J., Hitt, R., Opitz, L., SchulzSchaeffer, W. J., Hunsmann, G., and Motzkus, D. (2009). Upregulation of miRNA hsa-miR-342-3p in experimental and idiopathic prion disease. Mol. Neurodegener. 4, 36.

Montecalvo, A., Larregina, A. T., Shufesky, W. J., Beer Stolz, D., Sullivan, M. L., Karlsson, J. M., Baty, C. J., Gibson, G. A., Erdos, G., Wang, Z., Milosevic, J., Tkacheva, O. A., Divito, S. J., Jordan, R., Lyons-Weiler, J., Watkins, S. C., and Morelli, A. E. (2012). Mechanism of transfer of functional microRNAs between mouse dendritic cells via exosomes. Blood 119, 756-766.

Morales, R., Duran-Aniotz, C., Castilla, J., Estrada, L. D., and Soto, C. (2011). De novo induction of amyloid-beta deposition in vivo. Mol. Psychiatry. doi: 10.1038/mp.2011.120

Morelli, A. E., Larregina, A. T., Shufesky, W. J., Sullivan, M. L., Stolz, D. B., Papworth, G. D., Zahorchak, A. F., Logar, A. J., Wang, Z., Watkins, S. C., Falo, L. D. Jr., and Thomson, A. W. (2004). Endocytosis, intracellular sorting, and processing of exosomes by dendritic cells. Blood 104, 3257-3266.

Munch, C., O'Brien, J., and Bertolotti, A. (2011). Prion-like propagation of mutant superoxide dismutase1 misfolding in neuronal cells. Proc. Natl. Acad. Sci. U.S.A. 108, 3548-3553.

Murakami, K., Irie, K., Morimoto, A., Ohigashi, H., Shindo, M., Nagao, M., Shimizu, T., and Shirasawa, T. (2002). Synthesis, aggregation, neurotoxicity, and secondary structure of various A beta 1-42 mutants of familial Alzheimer's disease at positions 21-23. Biochem. Biophys. Res. Commun. 294, 5-10.

Nelson, P. T., and Wang, W. X. (2010). MiR-107 is reduced in Alzheimer's disease brain neocortex: validation study. J. Alzheimers Dis. 21, 75-79.

Orru, C. D., Hughson, A. G., Race, B., Raymond, G. J., and Caughey, B. (2012). Time course of prion seeding activity in cerebrospinal fluid of scrapie-infected hamsters after intratongue and intracerebral inoculations. J. Clin. Microbiol. 50, 1464 1466.

Patel, N., Hoang, D., Miller, N., Ansaloni, S., Huang, Q., Rogers, J. T., Lee, J. C., and Saunders, A. J. (2008). MicroRNAs can regulate human
APP levels. Mol Neurodegener $3,10$.

Pegtel, D. M., Cosmopoulos, K., Thorley-Lawson, D. A., Van Eijndhoven, M. A., Hopmans, E. S., Lindenberg, J. L., De Gruijl, T. D., Wurdinger, T., and Middeldorp, J. M. (2010). Functional delivery of viral miRNAs via exosomes. Proc. Natl. Acad. Sci. U.S.A. 107, 6328-6333.

Pigati, L., Yaddanapudi, S. C., Iyengar, R., Kim, D. J., Hearn, S. A., Danforth, D., Hastings, M. L., and Duelli, D. M. (2010). Selective release of microRNA species from normal and malignant mammary epithelial cells. PLoS ONE 5, e13515. doi:10.1371/journal.pone.0013515

Potolicchio, I., Carven, G. J., Xu, X., Stipp, C., Riese, R. J., Stern, L. J., and Santambrogio, L. (2005). Proteomic analysis of microglia-derived exosomes: metabolic role of the aminopeptidase CD13 in neuropeptide catabolism. J. Immunol. 175, 2237-2243.

Prusiner, S. B. (1982). Novel proteinaceous infectious particles cause scrapie. Science 216, 136-144.

Rabinowits, G., Gercel-Taylor, C., Day, J. M., Taylor, D. D., and Kloecker, G. H. (2009). Exosomal microRNA: a diagnostic marker for lung cancer. Clin. Lung Cancer 10, 42-46.

Rajendran, L., Honsho, M., Zahn, T. R., Keller, P., Geiger, K. D., Verkade, P., and Simons, K. (2006). Alzheimer's disease beta-amyloid peptides are released in association with exosomes. Proc. Natl. Acad. Sci. U.S.A. 103, 11172-11177.

Ratajczak, J., Miekus, K., Kucia, M., Zhang, J., Reca, R., Dvorak, P., and Ratajczak, M. Z. (2006). Embryonic stem cell-derived microvesicles reprogram hematopoietic progenitors: evidence for horizontal transfer of mRNA and protein delivery. Leukemia 20, 847-856.

Ren, P. H., Lauckner, J. E., Kachirskaia, I., Heuser, J. E., Melki, R., and Kopito, R. R. (2009). Cytoplasmic penetration and persistent infection of mammalian cells by polyglutamine aggregates. Nat. Cell Biol. 11, 219-225.

Saba, R., Goodman, C. D., Huzarewich, R. L., Robertson, C., and Booth, S. A. (2008). A miRNA signature of prion induced neurodegeneration. PLoS ONE 3, e3652. doi:10.1371/journal.pone. 0003652

Saba, R., Gushue, S., Huzarewich, R. L., Manguiat, K., Medina, S., Robertson, C., and Booth, S. A. (2012). MicroRNA 146a (miR-146a) is overexpressed during Prion disease and modulates the innate immune response and the microglial activation state. PLOS ONE 7, e30832. doi:10.1371/journal.pone.0030832

Saman, S., Kim, W., Raya, M., Visnick, Y., Miro, S., Jackson, B., Mckee, A. C. Alvarez, V. E., Lee, N. C., and Hall, G. F. (2011). Exosome-associated tau is secreted in tauopathy models and is selectively phosphorylated in cerebrospinal fluid (CSF) in early Alzheimer's disease. J. Biol. Chem. 287, 3842-3849.

Schonrock, N., Humphreys, D. T., Preiss, T., and Gotz, J. (2012). Target gene repression mediated by miRNAs miR-181c and miR-9 both of which are down-regulated by amyloidbeta. J. Mol. Neurosci. 46, 324-335.

Schonrock, N., Ke, Y. D., Humphreys, D., Staufenbiel, M., Ittner, L. M. Preiss, T., and Gotz, J. (2010). Neuronal microRNA deregulation in response to Alzheimer's disease amyloid-beta. PLoS ONE 5, e11070. doi:10.1371/journal.pone.0011070

Schorey, J. S., and Bhatnagar, S. (2008). Exosome function: from tumor immunology to pathogen biology. Traffic 9, 871-881.

Selkoe, D. J. (1996). Cell biology of the b-amyloid precursor protein and the genetics of Alzheimer's disease. Cold Spring Harb. Symp. Quant. Biol. 61, 587-596.

Serpell, L. C., and Smith, J. M. (2000). Direct visualisation of the b-sheet structure of synthetic Alzheimer's amyloid. J. Mol. Biol. 299, 225-231.

Sethi, P., and Lukiw, W. J. (2009). Micro-RNA abundance and stability in human brain: specific alterations in Alzheimer's disease temporal lobe neocortex. Neurosci. Lett. 459, 100-104.

Seubert, P., Oltersdorf, T., Lee, M. G., Barbour, R., Blomquist, C., Davis, D. L., Bryant, K., Fritz, L. C., Galasko, D., Thal, L. J., Lieberburg, I., and Schenk, D. B. (1993). Secretion of b-amyloid precursor protein cleaved at the amino terminus of the b-amyloid peptide. Nature 361 , 260-263.

Sharples, R. A., Vella, L. J., Nisbet, R. M., Naylor, R., Perez, K., Barnham, K. J., Masters, C. L., and Hill, A. F. (2008). Inhibition of gamma-secretase causes increased secretion of amyloid precursor protein C-terminal fragments in association with exosomes. FASEB J. 22 , 1469-1478.

Shioya, M., Obayashi, S., Tabunoki, H., Arima, K., Saito, Y., Ishida, T., and Satoh, J. (2010). Aberrant microRNA expression in the brains of neurodegenerative diseases: miR29a decreased in Alzheimer disease brains targets neurone navigator 3 . Neuropathol. Appl. Neurobiol. 36, 320-330.

Simons, M., and Raposo, G. (2009). Exosomes - vesicular carriers for intercellular communication. Curr. Opin. Cell Biol. 21, 575-581.

Skog, J., Wurdinger, T., Van Rijn, S., Meijer, D. H., Gainche, L., Sena-Esteves, M., Curry, W. T. Jr., Carter, B. S., Krichevsky, A. M., and Breakefield, X. O. (2008). Glioblastoma microvesicles transport RNA and proteins that promote tumour growth and provide diagnostic biomarkers. Nat. Cell Biol. 10, 1470-1476.

Smith, P. Y., Delay, C., Girard, J., Papon, M. A., Planel, E., Sergeant, N., Buee, L., and Hebert, S. S. (2011). MicroRNA-132 loss is associated with tau exon 10 inclusion in progressive supranuclear palsy. Hum. Mol. Genet. 20, 4016-4024.

Sun, D. M., Zhuang, X. Y., Xiang, X. Y., Liu, Y. L., Zhang, S. Y., Liu, C. R., Barnes, S., Grizzle, W., Miller, D., and Zhang, H. G. (2010). A novel nanoparticle drug delivery system: the anti-inflammatory activity of curcumin is enhanced when encapsulated in exosomes. Mol. Ther. 18, 1606-1614.

Taylor, A. R., Robinson, M. B., Gifondorwa, D. J., Tytell, M., and Milligan, C. E. (2007). Regulation of heat shock protein 70 release in astrocytes: role of signaling kinases. Dev. Neurobiol. 67, 1815-1829.

Taylor, D. D., and Gercel-Taylor, C. (2008). MicroRNA signatures of tumor-derived exosomes as diagnostic biomarkers of ovarian cancer. Gynecol. Oncol. 110, 13-21.

Taylor, D. R., and Hooper, N. M. (2006). The prion protein and lipid rafts. Mol. Membr. Biol. 23, 89-99.

Thery, C., Zitvogel, L., and Amigorena, S. (2002). Exosomes: composition, biogenesis and function. Nat. Rev. Immunol. 2, 569-579.

Tian, T., Wang, Y., Wang, H., Zhu, Z., and Xiao, Z. (2010). Visualizing of the cellular uptake and intracellular trafficking of exosomes by livecell microscopy. J. Cell. Biochem. 111, 488-496.

Tokuda, T., Qureshi, M. M., Ardah, M. T., Varghese, S., Shehab, S. A., Kasai, T., Ishigami, N., Tamaoka, A., Nakagawa, M., and El-Agnaf, O. M. (2010). Detection of elevated levels of alpha-synuclein oligomers in CSF from patients with Parkinson disease. Neurology 75, 1766-1772.

Trajkovic, K., Hsu, C., Chiantia, S. Rajendran, L., Wenzel, D., Wieland, 
F., Schwille, P., Brugger, B., and Simons, M. (2008). Ceramide triggers budding of exosome vesicles into multivesicular endosomes. Science 319, 1244-1247.

Tsigelny, I. F., Crews, L., Desplats, P., Shaked, G. M., Sharikov, Y., Mizuno, H., Spencer, B., Rockenstein, E., Trejo, M., Platoshyn, O., Yuan, J. X., and Masliah, E. (2008). Mechanisms of hybrid oligomer formation in the pathogenesis of combined Alzheimer's and Parkinson's diseases. PLoS ONE 3, e3135. doi:10.1371/journal.pone.0003135

Turchinovich, A., Weiz, L., Langheinz, A., and Burwinkel, B. (2011). Characterization of extracellular circulating microRNA. Nucleic Acids Res. 39, 7223-7233.

Valadi, H., Ekstrom, K., Bossios, A., Sjostrand, M., Lee, J. J., and Lotvall, J. O. (2007). Exosome-mediated transfer of mRNAs and microRNAs is a novel mechanism of genetic exchange between cells. Nat. Cell Biol. 9, 654-U672.

van den Boorn, J. G., Schlee, M., Coch, C., and Hartmann, G. (2011). SiRNA delivery with exosome nanoparticles. Nat. Biotechnol. 29, 325-326.

van Dommelen, S. M., Vader, P., Lakhal, S., Kooijmans, S. A., Van Solinge, W. W., Wood, M. J., and Schiffelers, R. M. (2011). Microvesicles and exosomes: Opportunities for cell-derived membrane vesicles in drug delivery. J. Control Release. doi: 10.1016/j.jconrel.2011.11.021

van Niel, G., Porto-Carreiro, I., Simoes, S., and Raposo, G. (2006). Exosomes: a common pathway for a specialized function. J. Biochem. 140, 13-21.

Vandermeeren, M., Mercken, M., Vanmechelen, E., Six, J., Van De Voorde, A., Martin, J. J., and Cras, P. (1993). Detection of tau proteins in normal and Alzheimer's disease cerebrospinal fluid with a sensitive sandwich enzymelinked immunosorbent assay. J. Neurochem. 61, 1828-1834.

Vella, L. J., Greenwood, D. L., Cappai, R., Scheerlinck, J. P., and Hill, A. F. (2008). Enrichment of prion protein in exosomes derived from ovine cerebral spinal fluid. Vet. Immunol. Immunopathol. 124, 385-393.

Vella, L. J., Sharples, R. A., Lawson, V. A., Masters, C. L., Cappai, R., and Hill, A. F. (2007). Packaging of prions into exosomes is associated with a novel pathway of PrP processing. J. Pathol. 211, 582-590.

Vickers, K. C., Palmisano, B. T., Shoucri, B. M., Shamburek, R. D., and Remaley, A. T. (2011). MicroRNAs are transported in plasma and delivered to recipient cells by highdensity lipoproteins. Nat. Cell Biol. 13, 423-433.

Vidal, M., Mangeat, P., and Hoekstra, D. (1997). Aggregation reroutes molecules from a recycling to a vesiclemediated secretion pathway during reticulocyte maturation. J. Cell. Sci. 110(Pt 16), 1867-1877.

Vilardo, E., Barbato, C., Ciotti, M., Cogoni, C., and Ruberti, F. (2010). MicroRNA-101 regulates amyloid precursor protein expression in hippocampal neurons. J. Biol. Chem. 285, 18344-18351.

Vilette, D. (2008). Cell models of prion infection. Vet. Res. 39, 10.

Volpicelli-Daley, L. A., Luk, K. C., Patel, T. P., Tanik, S. A., Riddle, D. M., Stieber, A., Meaney, D. F., Trojanowski, J. Q., and Lee, V. M. (2011). Exogenous alpha-synuclein fibrils induce Lewy body pathology leading to synaptic dysfunction and neuron death. Neuron 72, 57-71.

Waehler, R., Russell, S. J., and Curiel, D. T. (2007). Engineering targeted viral vectors for gene therapy. Nat. Rev. Genet. 8, 573-587.
Wanet, A., Tacheny, A., Arnould, T., and Renard, P. (2012). miR-212/132 expression and functions: within and beyond the neuronal compartment. Nucleic Acids Res. doi: 10.1093/nar/gks151

Wang, F., Wang, X., Yuan, C. G., and Ma, J. (2010). Generating a Prion with bacterially expressed recombinant prion protein. Science 327, 1132-1135.

Wang, F., Yang, F., Hu, Y., Wang, X., Wang, X., Jin, C., and Ma, J. (2007). Lipid interaction converts prion protein to a PrPSc-like proteinase Kresistant conformation under physiological conditions. Biochemistry 46 , 7045-7053.

Wang, W. X., Huang, Q., Hu, Y., Stromberg, A. J., and Nelson, P. T. (2011). Patterns of microRNA expression in normal and early Alzheimer's disease human temporal cortex: white matter versus gray matter. Acta Neuropathol. 121, 193-205.

Wang, W. X., Rajeev, B. W., Stromberg, A. J., Ren, N., Tang, G., Huang, Q., Rigoutsos, I., and Nelson, P. T. (2008). The expression of microRNA miR-107 decreases early in Alzheimer's disease and may accelerate disease progression through regulation of beta-site amyloid precursor proteincleaving enzyme 1. J. Neurosci. 28, 1213-1223.

Wilham, J. M., Orru, C. D., Bessen, R. A., Atarashi, R., Sano, K., Race, B., Meade-White, K. D., Taubner, L. M., Timmes, A., and Caughey, B. (2010). Rapid end-point quantitation of prion seeding activity with sensitivity comparable to bioassays. PLoS Pathog. 6, e1001217. doi:10.1371/journal.ppat.1001217

Wubbolts, R., Leckie, R. S., Veenhuizen, P. T., Schwarzmann, G., Mobius, W., Hoernschemeyer, J., Slot, J. W.
Geuze, H. J., and Stoorvogel, W. (2003). Proteomic and biochemical analyses of human B cell-derived exosomes. Potential implications for their function and multivesicular body formation. J. Biol. Chem. 278, 10963-10972.

Yamazaki, T., Koo, E. H., and Selkoe, D. J. (1996). Trafficking of cellsurface amyloid b-protein precursor.2. Endocytosis, recycling, and lysosomal targeting detected by immunolocalization. J. Cell. Sci. 109, 999-1008.

Yang, M., Chen, J., Su, F., Yu, B., Lin, L., Liu, Y., Huang, J. D., and Song, E. (2011). Microvesicles secreted by macrophages shuttle invasionpotentiating microRNAs into breast cancer cells. Mol. Cancer 10, 117.

Conflict of Interest Statement: The authors declare that the research was conducted in the absence of any commercial or financial relationships that could be construed as a potential conflict of interest.

Received: 15 March 2012; paper pending published: 26 March 2012; accepted: 13 April 2012; published online: 03 May 2012.

Citation: Bellingham SA, Guo BB, Coleman BM and Hill AF (2012) Exosomes: vehicles for the transfer of toxic proteins associated with neurodegenerative diseases? Front. Physio. 3:124. doi: 10.3389/fphys.2012.00124

This article was submitted to Frontiers in Membrane Physiology and Biophysics, a specialty of Frontiers in Physiology. Copyright (c) 2012 Bellingham, Guo, Coleman and Hill. This is an open-access article distributed under the terms of the Creative Commons Attribution Non Commercial License, which permits noncommercial use, distribution, and reproduction in other forums, provided the original authors and source are credited. 